\title{
Mineralogy of soils of major geomorphic units of north-eastern Haryana, India
}

\author{
Dinesh*, Mohammad Amin Bhat, K. S. Grewal, Hardeep Singh Sheoran \\ Department of Soil Science, CCS Haryana Agricultural University, Hisar -125004 (Haryana), INDIA \\ *Corresponding author. E-mail: dineshtomarhau@gmail.com
}

Received: August 14, 2016; Revised received: January 6, 2017; Accepted: April 30, 2017

\begin{abstract}
The study was carried to determine the mineralogy of soils of different geomorphic units for providing the more detailed information needed to improve agricultural production in north-eastern part of Haryana. The soils of the study area were slightly acidic to strongly alkaline in reaction (6-9.4). The cation exchange capacity and electrical conductivity varied from $3.10-26.80 \mathrm{cmol}^{(+)} \mathrm{kg}^{-1}$ and $0.16-1.20 \mathrm{dSm}^{-1}$, respectively. In general, the soils were siliceous in nature with $\mathrm{SiO}_{2}$ ranging from 68.60 to 87.90 percent. The soil samples from surface and subsurface diagnostic horizons were studied through X-ray diffraction. In fine sand, quartz was the dominant mineral followed by feldspars, muscovite, hornblende, tourmaline, zircon, biotite, iron ores and sphene. In silt fraction, quartz was the dominant mineral followed by mica, feldspars, chlorite, kaolinite, interstratified and traces of smectite and vermiculite. Semi-quantitative estimation of clay fraction indicated that illite was the single dominant mineral in the clay fraction of these pedons, however, its quantity was less in alluvial plains (28-30\%) compared to Shiwalik hills (36-49 \%). Next to illite, a high amount of smectite (14-20\%) and vermiculite (11-17\%) were observed in clays of alluvial plains of Ghaggar (recent and old) whereas in Shiwalik hills (top and valley) these minerals were detected in small amount $(6-11 \%)$. Fairly good amount of kaolinite (10-17\%) and small amount of chlorite (4-11\%) were uniformly distributed in soil clays irrespective of geomorphic units showing their detrital origin. Medium intensity broad peaks in higher range diffractograms $\left(14-24 \mathrm{~A}^{\circ}\right)$ indicated the presence of regular and irregular interstratified minerals in old alluvial plains of Ghaggar.
\end{abstract}

Keywords: Geomorphic unit, X-ray diffraction, Mineralogy, Diffractograms, Interstratified minerals

\section{INTRODUCTION}

A geomorphic surface or unit is defined as the part of the land surface with definite geographic boundaries formed by one or more agencies in a given period of time (Daniels et al., 1970; Buol et al., 2011). Four major geomorphic units have been recognized in northeastern Haryana. Shiwalik hills are primarily represented by Upper Shiwaliks extending from Kalesar in the southeast to northwest of Kalka. However, Middle Shiwaliks are present but in patches. Shiwaliks are also exposed on the northeastern border of Punjab in continuation in a linear lithotectonic belt. Immediately south of the low structural cum denudational hills of the Shiwalik, lies the zone of piedmont deposits. Within this geomorphic unit, two distinct generations of piedmont deposits are evident, an older piedmont zone which has later been cut and partly eroded by a younger piedmont deposit. This piedmont zone mainly comprises of alluvial coalescing fans and fan cut terrace deposits. This older alluvial tract occupies a position between the hills in the northeast and the aeolian zone to the southwest. There is a conspicuous variation in the geomorphological set up to the north and south of the Ghaggar river. The southern tract shows the prevalence of dunal features and is differentiated by sand ridges upto $15 \mathrm{~m}$ high and $5 \mathrm{~km}$ long. However, northern tract exhibits low relief, stabilized dunes, marginal dunes occurring periodically in patches. The low-lying areas in the immediate vicinity of the major rivers viz. the Yamuna, the Sutlej, the Beas and the Ravi characterized by typical features of recent flood plain have been classified as flood plain. This distinguishable geomorphic unit, due to frequent inundation during high flash floods and owing to its low-lying nature, has no optimum land use pattern or planning. This is in fact the younger alluvium and is put under seasonal cultivation when free from floods (Chopra, 1990).

Topography plays a prominent role in determining the variation of soil properties, since such variations are on account of the orientation of hill slope on which the soil is formed. Moreover, the steep slopes, in general, promote rapid loss of soil by erosion as a result of low infiltration leading to excessive runoff (Brady and Weil, 2007). It not only conditions the microclimate but also influences soil properties by affecting multitude of soil forming processes. Understanding soil genesis needs elucidation of the chemical, mineralogical and physical composition of the soil because these properties determine the utility of the soils for sustainable agricultural production. Amidst the ultimate products of weathering, clay minerals and mineral colloids 
of various characteristics are influencing numerous soil properties in various ways (Churchman, 2010a). Clay minerals are hydrated aluminum silicates with very fine particle size, usually $<2 \mu \mathrm{m}$ (Moore and Reynolds, 1989). The permutations of minerals are largely related with nature and constitution of parent material and degree of weathering (Abbaslou et al., 2013). Owing to the rationales of primary mineral stability, alteration and neoformation of minerals, it is apparent that all soils develop from parent rocks and their elemental constitution begins to rely more on weathering environs rather on composition of parent materials. Therefore, associations of clay minerals in soils are regarded as indices of degree of soil development (McBride, 1994). Churchman (2010b) reported that, in general, minerals formed by neogenesis from solutions in the soil appear in smaller particles showing more disorder compared to other processes, for instance, hydrothermally or from deposits of oceanic or lacustrine origin. Since, little research has been carried out to compare the mineralogical composition of soils under different landscapes, therefore, clay mineralogy and the properties of the soils with different topography and vegetation were analysed. The aim of this work was to determine the relationship between geomorphic units and the mineralogy of the soil.

\section{MATERIALS AND METHODS}

The study area is situated between $76^{\circ} 31^{\prime}$ to $77^{\circ} 35^{\prime} \mathrm{E}$ longitudes and $30^{\circ} 03^{\prime}$ to $30^{\circ} 57^{\prime} \mathrm{N}$ latitudes covering districts of Panchkula, Ambala, Yamuna Nagar and Kurukshetra in Haryana. Most of the area is covered by quaternary deposits except hilly area. The general topography is undulating in the northern part and flat in the southern part. Geomorphologically, the area comprises of hilly terrain, piedmont plain and alluvial plain. Two major rivers flow through this area, Ghaggar and Yamuna. The climate is subtropical, semiarid, continental monsoonal with prolonged hot summer with mean annual precipitation of 578-1486 $\mathrm{mm}$. The

Table 1. General characteristics of geomorphic units of north-eastern Haryana.

\begin{tabular}{lllll}
\hline Pedon & Physiography & Drainage & Erosion & Land use \\
1 & Shiwalik hill (Top) & Excessively drained & Very severe & Forest \\
2 & Shiwalik hill (Top) & Very severe & Forest (wasteland) \\
3 & Shiwalik hill (Slope) & Runoff & Very severe & Forest \\
4 & Shiwalik hill (Slope) & Runoff & Very severe & Forest \\
5 & Shiwalik hill (Valley) & Excessively drained & Severe & Forest \\
6 & Shiwalik hill (Valley) & Well drained & Cultivation \\
7 & Shiwalik hill (Valley)-gently undulating & Moderately well drained & Moderate & Cultivation \\
8 & Shiwalik hill (Valley) & Imperfectly drained & Moderate & Forest \\
9 & Shiwalik hill (Valley) & Imperfectly drained & Severe & Grasses, wasteland \\
10 & Piedmont plain (Upper) & Well drained & Severe & Forest \\
11 & Piedmont plain (Upper) - gently undulating & Moderate & Severe & Fallow and wheat \\
12 & Piedmont plain (Upper) - gently to very & Moderate & Moderate & Fallow and wheat \\
& gently undulating & & & \\
13 & Piedmont plain (Lower) - very gently un- & Well drained & Moderate & Cultivation \\
& dulating & & & \\
14 & Piedmont plain (Lower) - nearly level & Well drained & Absent & Cultivation \\
15 & Active floodplain (Ghaggar) & Well drained & Slight & Cultivation \\
16 & Recent flood plain (Ghaggar) & Well drained & Absent & Cultivation \\
17 & Recent flood plain (Yamuna) & Moderately well drained & Slightly to moderate & Cultivation \\
18 & Old alluvial plain (Ghaggar) & Well drained & Absent & Cultivation \\
19 & Old alluvial plain (Markhanda) & Poorly drained & Absent & Cultivation \\
20 & Old alluvial plain (Yamuna) & Imperfectly drained & Absent & Cultivation \\
21 & Low lying plain & Imperfect & Absent & Forest \\
22 & Low lying plain & Imperfectly drained & Absent & Cultivation \\
\hline
\end{tabular}

Table 2. Semi-quantitative estimation of clay minerals in clay fraction $(<2 \mu)$ of soils.

\begin{tabular}{llllllllllll}
\hline Geomorphic unit & Pedon & Horizon & Depth (cm) & I & V & S & K & C & Q & F & Inter. \\
\hline Shiwalik hill (Top) & 2 & A1 & $0-37$ & 48 & 6 & 10 & 13 & 11 & $<5$ & - & 10 \\
Shiwalik hill (Top) & 2 & 2C & $152-242$ & 49 & 6 & 12 & 12 & 9 & 5 & - & 7 \\
Shiwalik hill (Valley) & 5 & A1 & $0-23$ & 43 & 12 & 9 & 12 & 10 & 5 & - & 9 \\
Shiwalik hill (Valley) & 5 & C & $53-106$ & 36 & 11 & 17 & 13 & 8 & 8 & $<5$ & 5 \\
Shiwalik hill (Valley) & 9 & Ap & $0-6$ & 43 & 15 & 6 & 15 & 7 & 5 & - & 9 \\
Shiwalik hill (Valley) & 9 & C & $31-48$ & 46 & 13 & 7 & 14 & 8 & 6 & - & 6 \\
Active Flood Plain (Ghaggar) & 15 & Ap & $0-26$ & 28 & 17 & 20 & 10 & 5 & 5 & - & 15 \\
Active Flood Plain (Ghaggar) & 15 & 2C & $86-120$ & 31 & 12 & 16 & 15 & 4 & 6 & - & 16 \\
Active Flood Plain (Ghaggar) & 18 & Ap & $0-17$ & 34 & 13 & 15 & 17 & 5 & 6 & - & 10 \\
Active Flood Plain (Ghaggar) & 18 & B2 & $20-50$ & 39 & 11 & 14 & 15 & 7 & 5 & - & 9 \\
\hline
\end{tabular}

$\mathrm{I}=$ =Ilite, $\mathrm{K}=$ Kaolinite, $\mathrm{C}=$ Chlorite, $\mathrm{S}=$ Smectite, $\mathrm{V}=$ Vermiculite, $\mathrm{Q}=$ Quartz, $\mathrm{F}=$ Feldspar, Inter= Interstratified 
Dinesh et al. / J. Appl. \& Nat. Sci. 9 (2): 924 - 934 (2017)

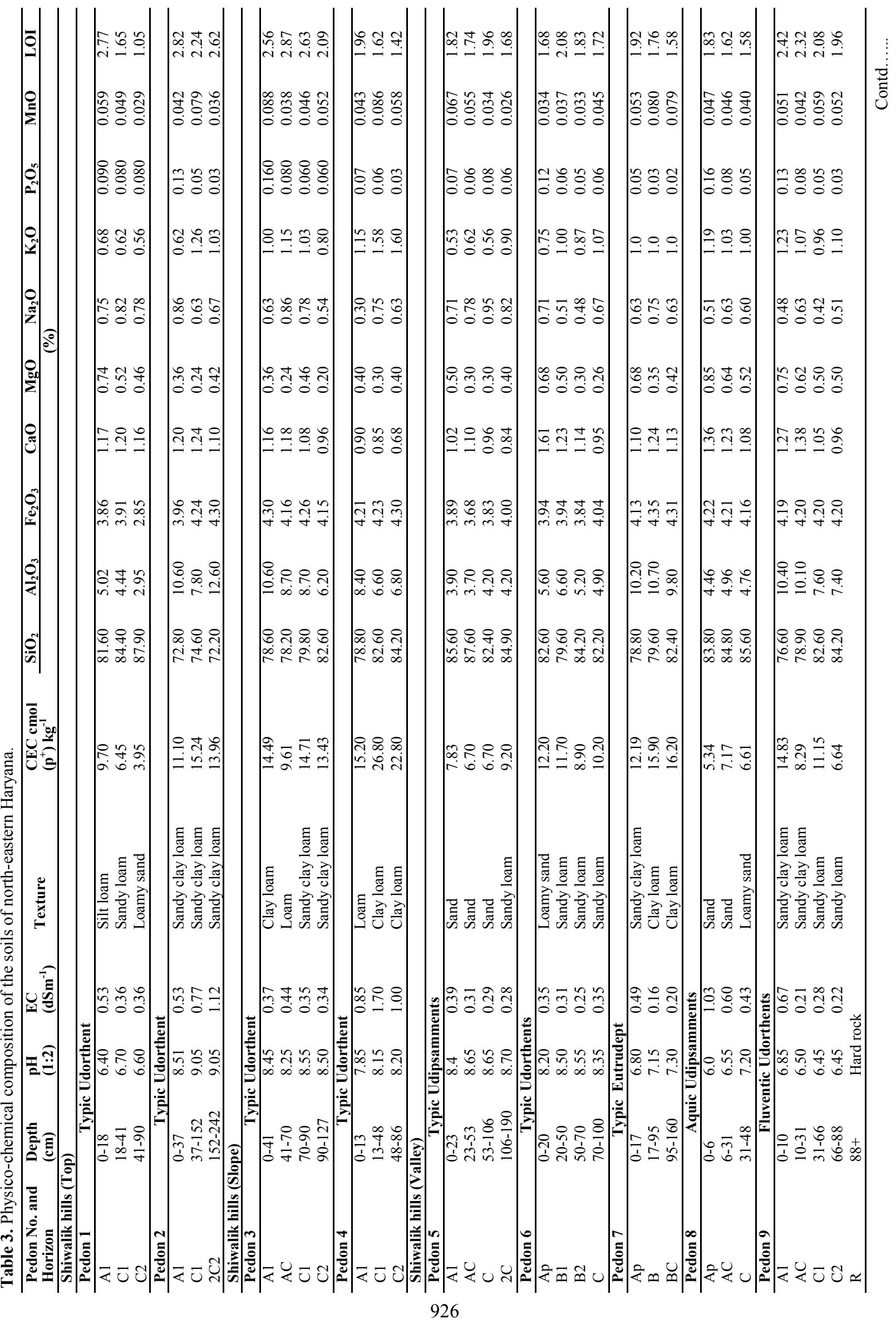


Dinesh et al. / J. Appl. \& Nat. Sci. 9 (2): 924 - 934 (2017)

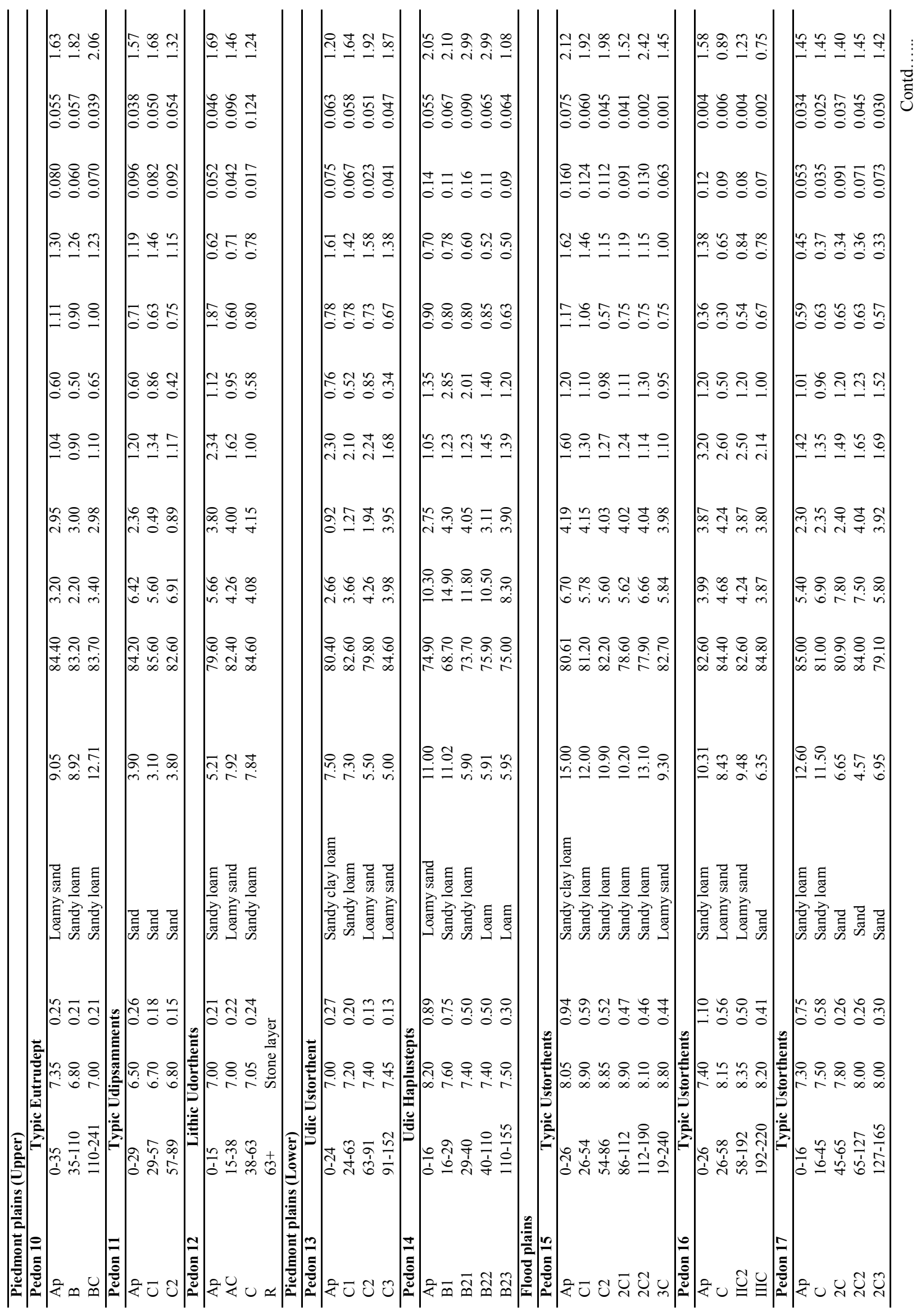


Dinesh et al. / J. Appl. \& Nat. Sci. 9 (2): 924 - 934 (2017)

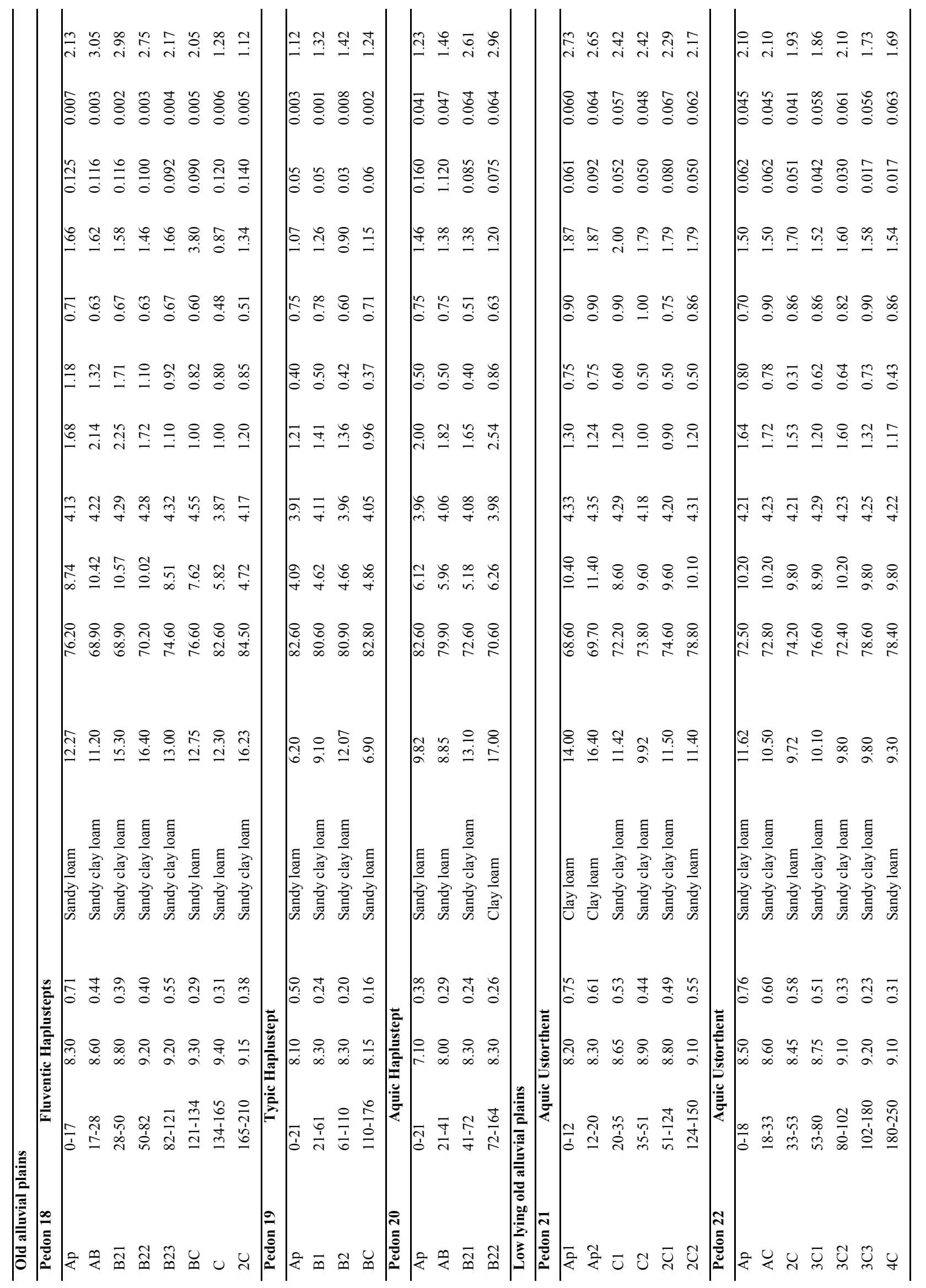




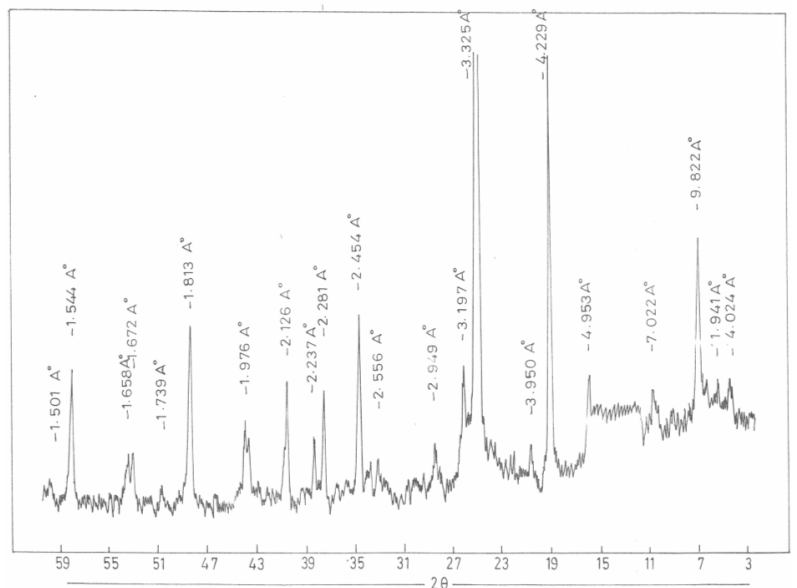

Fig. 1. X-ray diffractograms of silt fraction $(2 \mu)$ of pedon 2 Shiwalik Hill Top (Ap: 0-37).

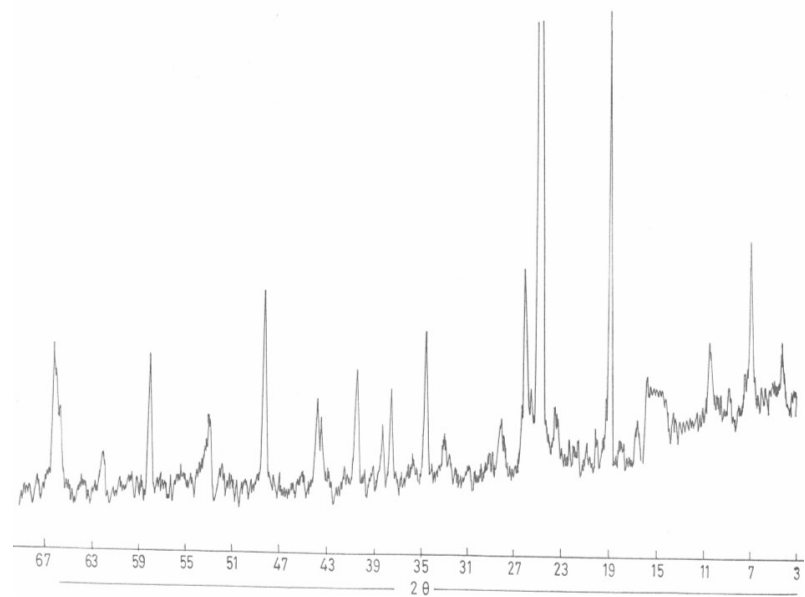

Fig. 2. X-ray diffractograms of silt fraction $(2 \mu)$ of pedon 8 Shiwalik Hill Valley (Ap: 0-17).

maximum rainfall occurs during monsoon i.e., July to September. The soil moisture regime is ustic and udic and soil temperature regime is hyperthermic. The soil of Shiwalik hill (top and valley) and recent flood plains of Ghaggar were Typic Udorthents/ Udipsamments and soils of old alluvial plains of Ghaggar were Typic Haplustepts (Soil Survey Staff, 2006). Topographic maps of India $(1: 50,000)$ were used to identify sites for profile excavation and soil augering. On the basis of geomorphic-soil relationship established in the area, 22 representative pedons were exposed and studied in the field. These pedons also form a toposequence, a transect covering from Shiwalik hills to lower alluvial plains. The 22 profiles were selected during an inventory of the characteristics and variability of the different soil types. The soils chosen were assumed to be representative of the area. Sampling of each pedon was done by pedological horizon; $2-3 \mathrm{~kg}$ of soil was collected per horizon. A total of 120 samples were collected, air-dried, ground using wooden pestle and mortar and passed through a $2 \mathrm{~mm}$ sieve. Soil samples were analysed for $\mathrm{pH}$, electrical conduc-

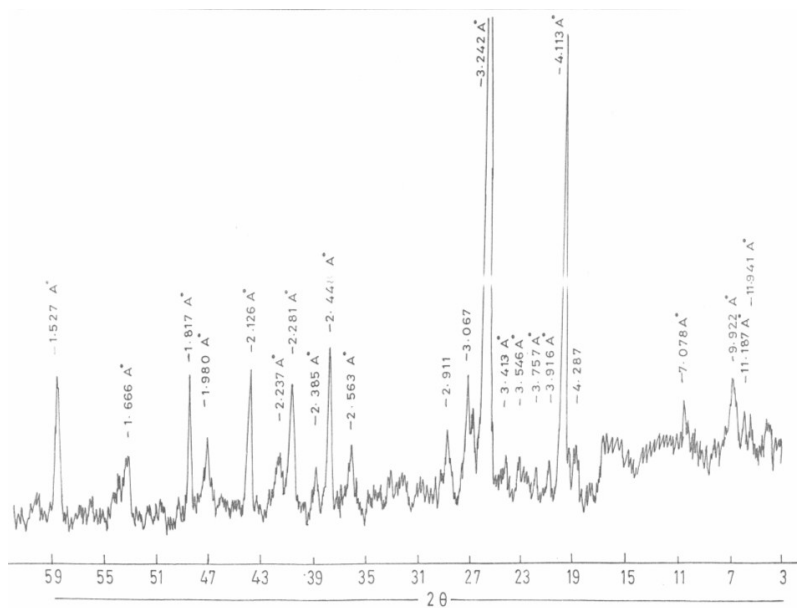

Fig. 3. X-ray diffractograms of silt fraction $(2 \mu)$ of pedon 15 Active Flood Plain (Ghaggar) (Ap: 0-26).

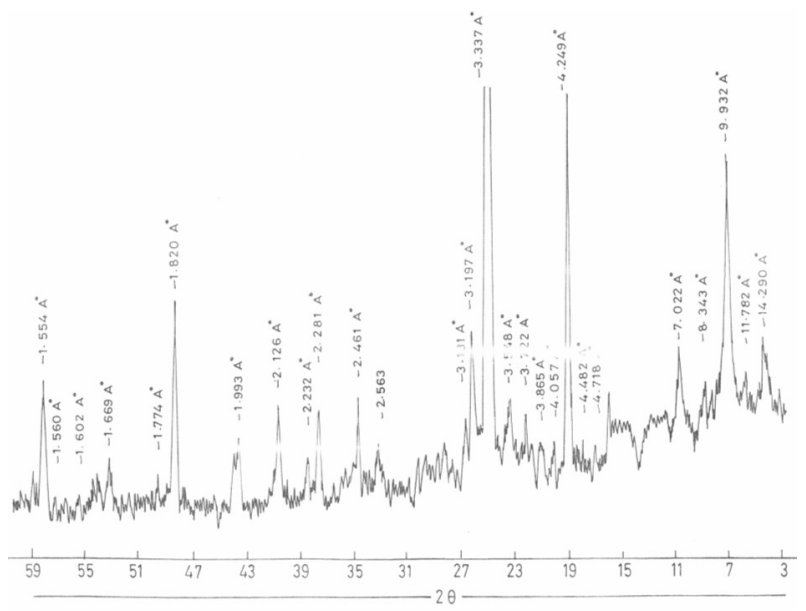

Fig. 4. X-ray diffractograms of silt fraction $(2 \mu)$ of pedon 18 Old Alluvial Plain (Ghaggar) (Ap: 0-17).

tivity $\left(\mathrm{EC}_{\mathrm{e}}\right)$ cation exchange capacity (CEC) and texture using standard procedures (Soil Conservation Service, 1972). Based on physico-chemical characteristics, 10 soil samples representing different soil horizons were selected for detailed mineralogical analysis. The mineralogical composition of soils was determined by X-ray diffraction analysis (XRD). The XRD analysis was conducted on the clay fraction isolated from soils that were pre-treated with $\mathrm{H}_{2} \mathrm{O}_{2}$. For removal of soil organic matter $10 \mathrm{~g}$ of $2 \mathrm{~mm}$ air dried sample was weighed into a $1000 \mathrm{ml}$ beaker and treated with $30 \%$ $\mathrm{H}_{2} \mathrm{O}_{2}$ until effervescence ceases followed by heating to about $90 \square$ to remove excess $\mathrm{H}_{2} \mathrm{O}_{2}$. The sample was washed with distilled water before transferring into a $250 \mathrm{ml}$ centrifuge tube. The soil was dispersed by $\mathrm{Na}_{2} \mathrm{CO}_{3}$ and the clay fraction was isolated by sedimentation. The following treated slides were scanned: $\mathrm{Mg}$ saturated, Mg-saturated and glycerol solvated, $\mathrm{K}$ saturated, $\mathrm{K}$-saturated and heated, $\mathrm{HCl}$ treated $\mathrm{Mg}$ saturated and $\mathrm{HCl}$ treated and then $\mathrm{Mg}$ saturatedglycerol solvated clays were prepared as oriented specimen and mounted on glass slides, analysed on 


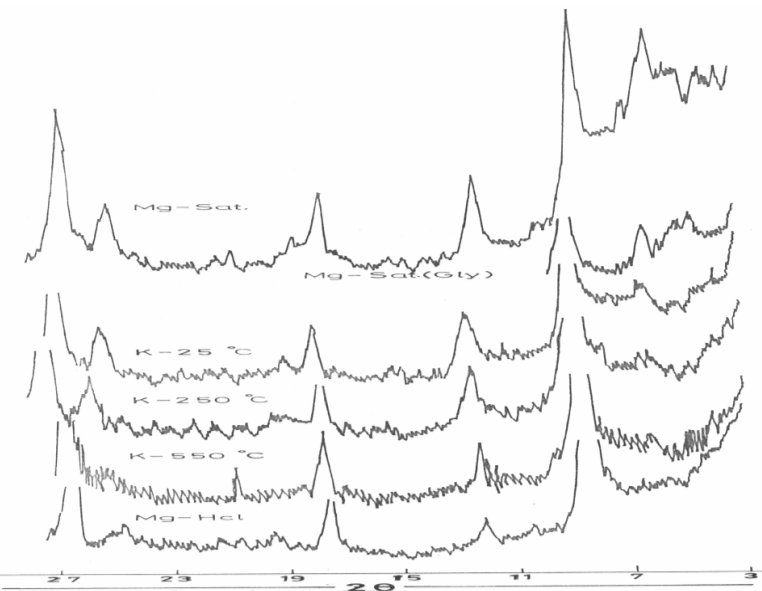

Fig. 5. X-ray diffractograms of clay fraction $(2 \mu)$ of pedon 2 of Shiwalik hills Top $\left(A_{1}: 0-37\right)$.

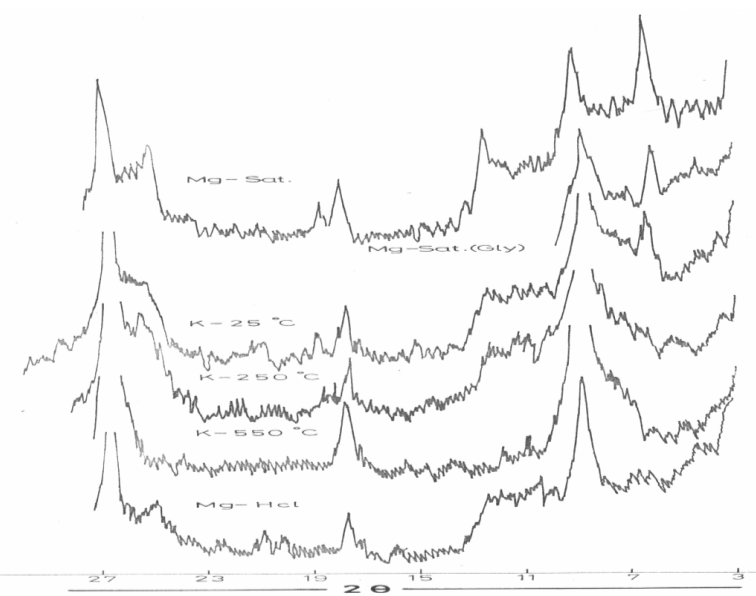

Fig. 6. X-ray diffractograms of clay fraction $(2 \mu)$ of pedon 2 of Shiwalik hills Top (II $I_{c}$ 152-200).

Philips PW 1390 X-ray diffractometer using Nifiltered $\mathrm{CuK} \alpha$-radiation target and operated at $30 \mathrm{KV}$ and $20 \mathrm{~mA}$. Semi-quantitative estimates were prepared on the basis of relative peak area ratio after necessary correction for background (Gjems, 1967; Ghosh and Dutta, 1974; Karanthansis and Hajek, 1982). The total oxide concentrations in the soil samples were obtained by X-ray fluorescence spectrometry using glass beads method.

\section{RESULTS AND DISCUSSION}

The general site characteristics of the soils developed on four major geomorphic units of north-eastern Haryana viz., Shiwalik hills, piedmont plains, flood plains and old alluvial plains are given in Table 1. The soils had various parent materials and the land forms were flaty to gently undulating. The horizonation of different profiles is shown in table 3. The land use, by and large, included chir pines, bamboo, shisham, mulberry etc (forests) and wheat, mustard, barley, paddy etc.

Physico-chemical properties: The texture of different geomorphic units is shown in Table 2. In each loca-

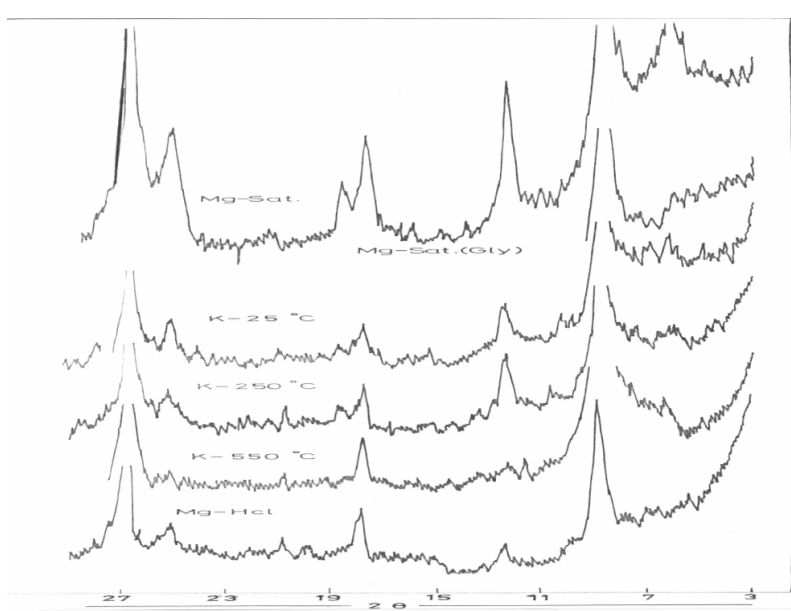

Fig. 7. X-ray diffractograms of clay fraction $(2 \mu)$ of pedon 5 of Shiwalik hills valley $\left(A_{1}: 0-23\right)$.

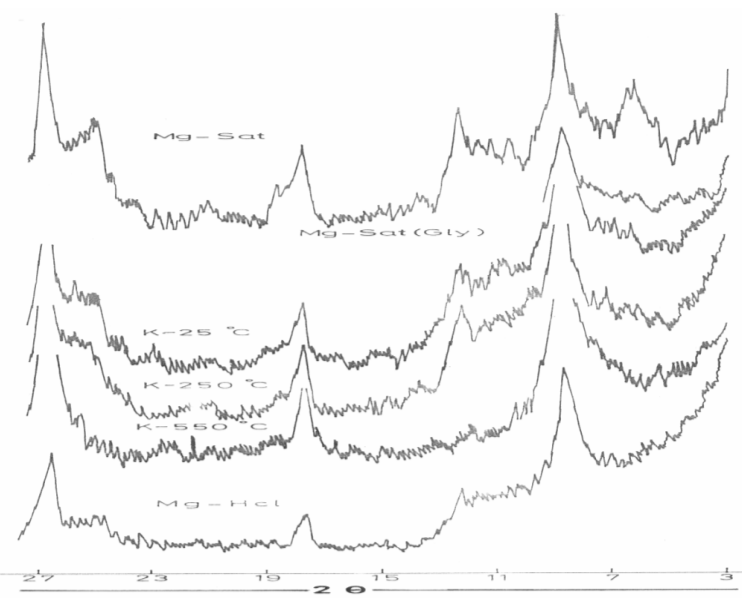

Fig. 8. X-ray diffractograms of clay fraction $(2 \mu)$ of pedon 5 of Shiwalik hills valley (C: 53-106).

tion, soils mostly had quite different textures. At some locations individual soil profiles had very different textures relative to other profiles at that location. Some profiles showed a systematically increasing clay percentage with depth (pedon 7) that could be attributed to pedogenesis (illuviation) but could also reflect the presence of sedimentary layers deposited under a regime where transport conditions become more energetic over time (Wongpokhom et al. 2008).

The results reveal that the soils in terms of chemical reaction varied from slightly acidic to strongly alkaline. There was a substantial variation in $\mathrm{pH}$ in different locations. According to $\mathrm{pH}$ classes, described by Soil Survey Staff (2006), the soils of pedon 1 (Shiwalik hills-top), pedons 7, 8 and 9 (valleys), pedons 10, 11 and 12 (upper piedmont plains) were slightly acidic to neutral (6-7.35) in reaction which may be due to high rainfall and more vegetation in the area. The soils of pedon 3 and 4 (Shiwalik hill-slope), pedons 5 and 6 (valleys), pedon 14 (lower piedmont plains), pedons 16 and 17 (flood plains) and pedon 20 (old alluvial plain) were moderately alkaline (7.8 to 


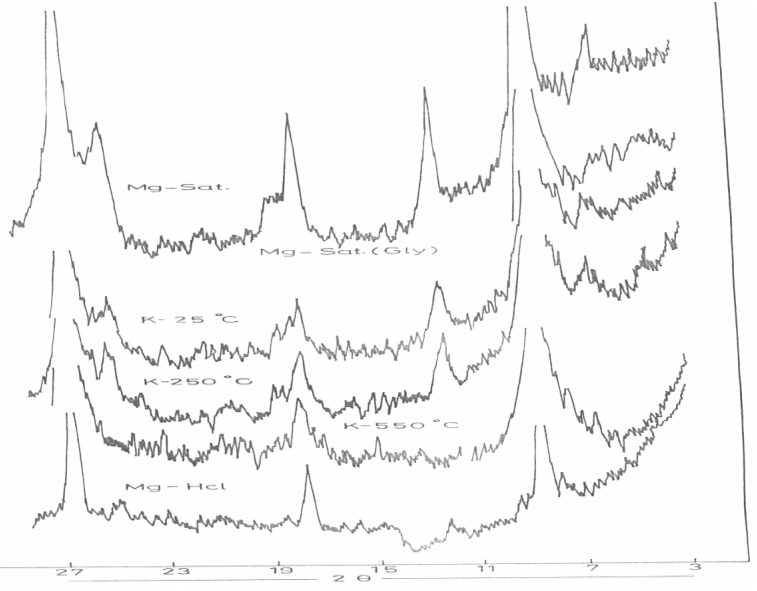

Fig. 9. X-ray diffractograms of clay fraction $(2 \mu)$ of pedon 8 of Shiwalik hills valley (Ap: 0-6).

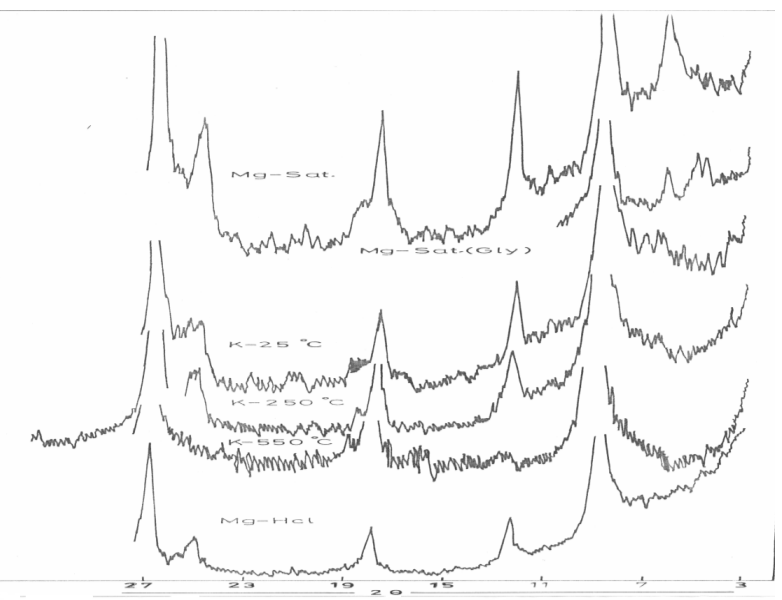

Fig. 10. X-ray diffractograms of clay fraction $(2 \mu)$ of pedon 8 of Shiwalik hills valley (C: 31-48).

8.3 ) in reaction whereas pedons $2,15,18,19,21$ and 22 were strongly alkaline (8.3 to 9.4$)$ in reaction. There was an increase in $\mathrm{pH}$ with depth in all pedons except 9 and 14 which might be attributed to the loss of bases from the surface. The increase in $\mathrm{pH}$ in deeper horizons was also reported by Kaistha and Gupta (1993) in the soils of the north-west Himalayan region. The cation exchange capacity was found to be less

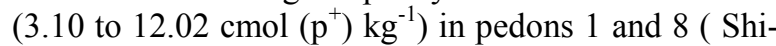
walik hills), pedons $10,11,12,13$ and 14 (piedmont plains) compared to pedons 2, 3 and 4 (Shiwalik hills), pedons 5, 6 and 7 (valleys), pedons 15 and 17 (flood plains) and pedons 18, 19, 20, 21 and 22 of old alluvial plains having (9.61 to $\left.17 \mathrm{cmol}\left(\mathrm{p}^{+}\right) \mathrm{kg}^{-1}\right)$. The low cation exchange capacity of these soils is due to dominance of illite and other low charge minerals and low organic matter content (Sharma et al., 2011). Lower horizons of pedon 4 had highest cation exchange capacity (22.20 to $\left.26.80 \mathrm{cmol}\left(\mathrm{p}^{+}\right) \mathrm{kg}^{-1}\right)$. The higher CEC in pedons $3,4,7,15,18$ and 21 may be related to variation in content and nature of organic carbon and inorganic colloids (Sireesha and Naidu, 2015). Sawhney et al. (1996) evinced that the wide variation in CEC

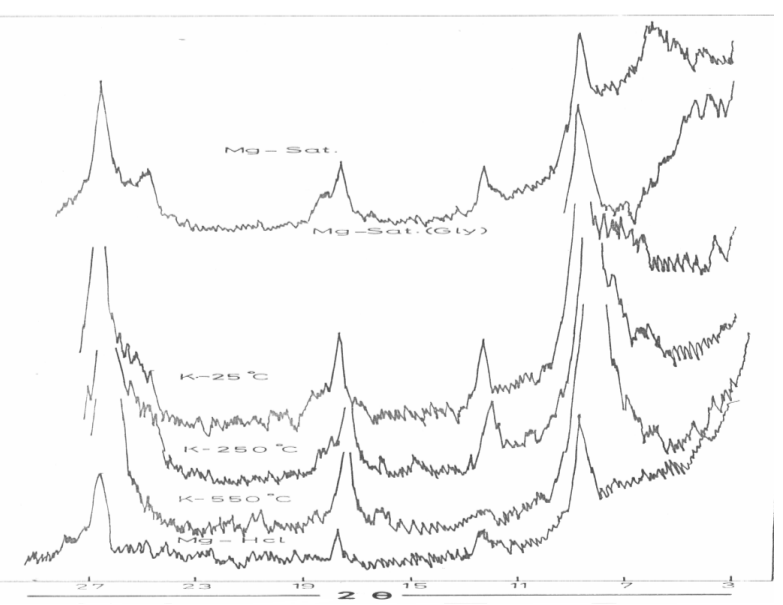

Fig. 11. X-ray diffractograms of clay fraction $(2 \mu)$ of pedon 15 Active Flood Plain (Ghaggar) (Ap: 0-26).

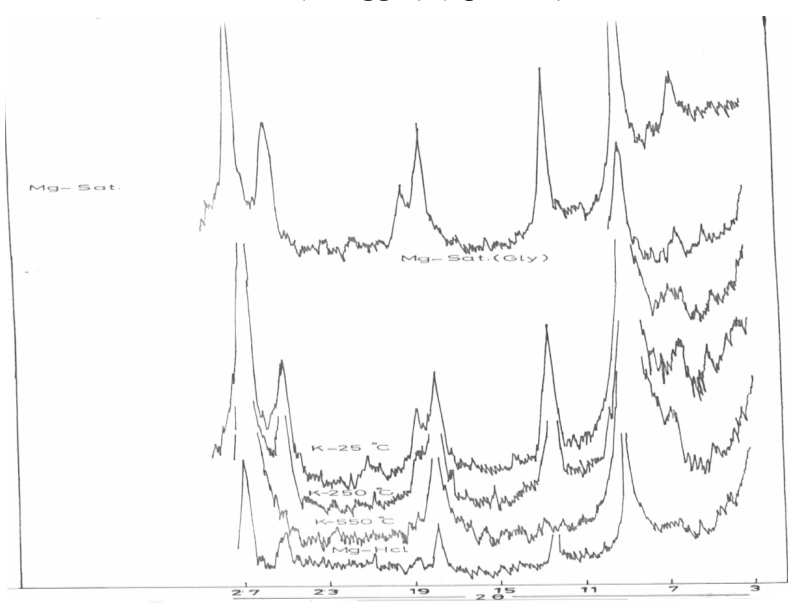

Fig. 12. X-ray diffractograms of clay fraction $(2 \mu)$ of pedon 15 Active Flood Plain (Ghaggar) (II $\left.I_{C l}: 86-112\right)$.

among different landscapes of Shiwalik hills of Punjab may be assigned to difference in clay content and stratified and young nature of materials. Sharma et al. (1997) reported that substantially wide variation of CEC (2.8-32.8 cmol $\left.\left(\mathrm{p}^{+}\right) \mathrm{kg}^{-1}\right)$ in Inceptisols of northwest India.

The electrical conductivity (EC) of saturation extract revealed that soils of all geomorphic units were nonsaline in nature $\left(0.16\right.$ to $\left.1.20 \mathrm{dSm}^{-1}\right)$. The EC of flood plains (pedons 15, 16, 17), old alluvial plains (pedons $18,19,20)$ and low lying alluvial plains (pedon 21, 22) was found to decrease with depth. The soils of Shiwalik hills (top and slope; pedons 1, 2, 3,4) valleys (pedons 5, 6, 7, 8, 9) and piedmont plains (pedons 10, $11,12,13,14)$ showed more electrical conductivity in subsurface horizons which might be due to high and erratic rainfall.

The chemical composition of soils observed to have been influenced not only by parent material but also to extent by pedo-environment including microclimate and geomorphology. In general, the soils were siliceous in nature with $\mathrm{SiO}_{2}$ ranging from 68.60 to 87.90 percent. The soils of Shiwalik hills (top and slope) and 


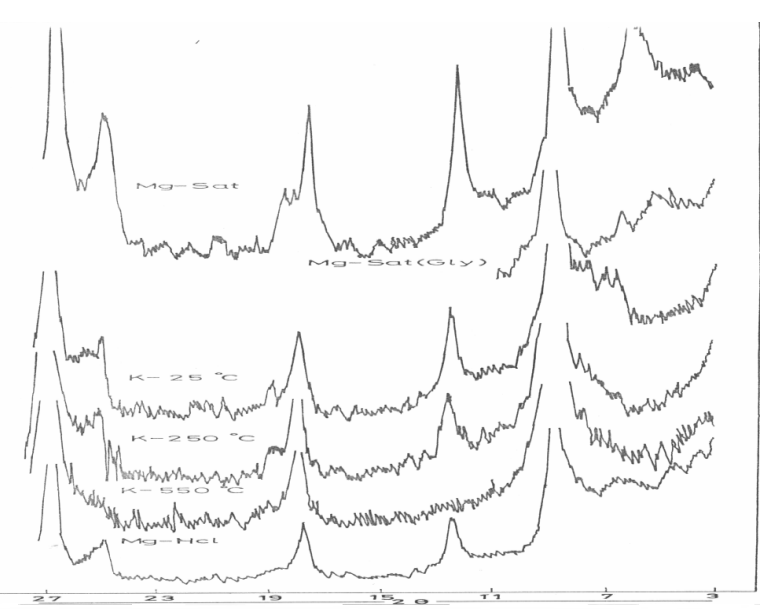

Fig. 13. X-ray diffractograms of clay fraction $(2 \mu)$ of pedon 18 Old Alluvial Plain (Ghaggar) (Ap: 0-17).

valleys were having more $\mathrm{SiO}_{2}(72.2$ to $87.9 \%)$ than old alluvial plains and low lying alluvial plains (68.8 to $78.8 \%$ ). This may be due to higher amount of quartz in parent material (Ahuja, 1981; Khan et al., 1997). Sireesha and Naidu (2015) reported that the values of $\mathrm{SiO}_{2}$ and $\mathrm{Al}_{2} \mathrm{O}_{3}$ reflect the presence of appreciable amount of 2:1 type of clay minerals. Walia and Rao (1997) reported that $\mathrm{SiO}_{2}$ varied from 59.7-76.8\% which may be attributed to the nature and source of alluvium in Trans-Yamuna plains. In pedons 1, 3, 7, 8 and 9 of Shiwalik hills, $\mathrm{SiO}_{2}$ increased with depth or exhibited no particular pattern which may be attributed to sediment deposition. The $\mathrm{SiO}_{2}$ in the horizons of flood plains (pedons 15, 17) and low lying alluvial plains (pedon 21) exhibited the decreasing pattern with depth which may be ascribed to deposition of finer alluvium in lower horizons. Aluminium and iron were important constituents of soils at all locations. The amount of $\mathrm{Al}_{2} \mathrm{O}_{3}$ and $\mathrm{Fe}_{2} \mathrm{O}_{3}$ varied from 2.2 to 14.7 percent and 0.49 to 4.55 percent, respectively and showed that the amount of $\mathrm{Al}_{2} \mathrm{O}_{3}$ increased with depth indicating the weathering of aluminosilicates and ferromagnesium minerals at the surface and then by leaching the B-horizons were enriched. Walia and Rao (1997) reported that increase in $\mathrm{Fe}_{2} \mathrm{O}_{3}$ content with depth suggests more iron bearing minerals in subsurface horizons. Yadav (1999) ascertained that $\mathrm{Al}_{2} \mathrm{O}_{3}$ and $\mathrm{Fe}_{2} \mathrm{O}_{3}$ varied from 4.8-18.1 and 1.35-8.49 \%, respectively in major landforms of Haryana. The amount of $\mathrm{CaO}$ and $\mathrm{MgO}$ varied from 0.68 to 3.83 and 0.31 to 1.71 percent, respectively. The irregular distribution of $\mathrm{CaO}$ and $\mathrm{MgO}$ showed the lithological discontinuity (pedons 2, 5, 8, 17, 18, 20, 22). The presence of $\mathrm{CaO}$ and $\mathrm{MgO}$ infer the occurrence of minerals rich in calcium and magnesium (Sireesha and Naidu, 2015). Sodium oxide $\left(\mathrm{Na}_{2} \mathrm{O}\right)$ and $\mathrm{K}_{2} \mathrm{O}$ were present in low amount, i.e, 0.26 to 1.87 and 0.50 to 3.80 percent, respectively. The presence of $\mathrm{Na}_{2} \mathrm{O}$ and $\mathrm{K}_{2} \mathrm{O}$ showed the weathering of sodium and potassium in feldspar minerals. Raina et al (2006) reported that $\mathrm{K}_{2} \mathrm{O}$ in all pedons

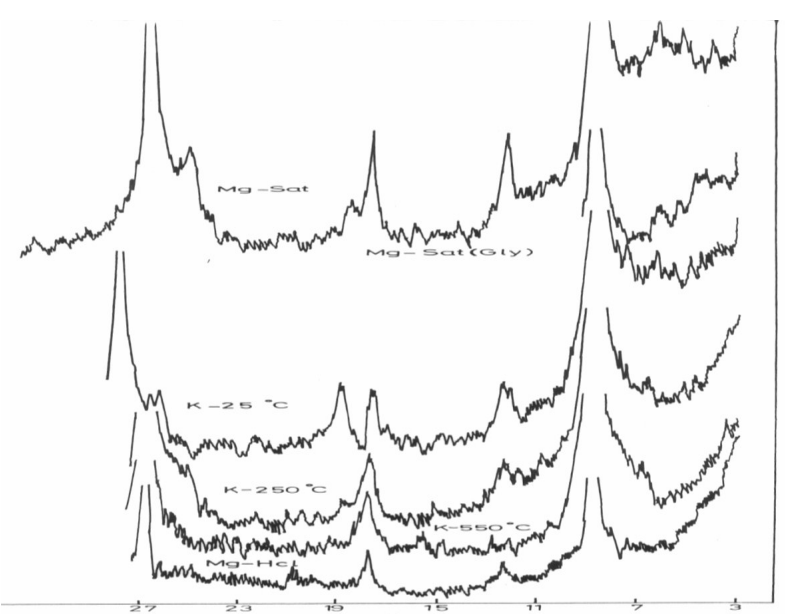

Fig. 14. X-ray diffractograms of clay fraction $(2 \mu)$ of pedon 18 Old Alluvial Plain (Ghaggar) (AB: 20-50).

indicates the presence of $\mathrm{K}$ bearing clay minerals i.e. micas and feldspars (Khan et al., 1997). The vertical distribution pattern of the above oxides within the profiles showed variation which indicated that pedochemical weathering processes were not intense enough to bring about any change in the distribution pattern of the silicate minerals containing these elements.

\section{Mineralogical properties}

Fine sand: The kind of the fine sand minerals and their order of abundance are presented in table 1 . The mineralogical properties of fine sand fraction revealed that quartz was dominant mineral followed by orthoclase-feldspars, muscovite, hornblende, tourmaline, zircon, biotite, iron ores and sphene. Heavy minerals were found more in subsurface horizons compared to light minerals in these areas. Mineralogical composition on Shiwalik hills, piedmont plains showed the advanced stage of weathering compared to flood plains and old alluvial plains. Ahuja et al. (1984) ascertained that the distribution of minerals and low degree of pedogenic development was mainly due to the influence of preservation of sediment sequences with less time and lower intensity of weathering in Ghaggar river basin of Haryana and Punjab. Gupta et al. (2009) described that quartz, feldspar and muscovite-mica were the main minerals in the light sand fraction and opaque type of minerals like zircon, tourmaline, augite, hornblende and biotite in heavy fractions of sand. Silt mineralogy: The silt mineralogy was almost similar to clay mineralogy with additional amount of feldspars. However, the distribution pattern of minerals in silt was reverse to that of clay. Quartz was the dominant mineral followed by mica except active flood plain (Ghaggar) where feldspar was the second most dominant mineral. On the contrary, mica content was relatively higher in silt fraction because it tends to concentrate in the finer fraction during the course of weathering (Sharma et al., 2011). Moreover, in silt fraction, feldspars were represented by both $\mathrm{K}$ - and $\mathrm{Na}$ -feldspars (albite). The relatively lower amount of 
feldspars in silt fraction compared to sand fraction may be due to the fact that the former has undergone more intense weathering due to increased fineness of the particles compared with later (Brindley and Brown, 1980; Sidhu, 1982; Sharma et al., 2011). Besides, small amounts of chlorite, kaolinite, interstratified and traces of smectite and vermiculite were observed. Although abundance of quartz was highest in silt fraction, its content was comparatively lower in sand fraction. Likewise, earlier investigations reported decrease in quartz content with reduction with particle size (Sidhu and Gilkes, 1977; Jassal et al., 2000). The diffractograms of silt fraction of pedons $2,8,15$ and 18 are presented in figures 1,2, 3 and 4, respectively.

Clay mineralogy: The semi-quantitative evaluation of the clay fraction is shown in tablel revealed that illite was the single dominant clay mineral in all the soils under study which may be ascribed to the dominance of micaceous rocks in the parent material (Sharma et al., 2011). However, its quantity was less in the old alluvial plain (Ghaggar) $28.39 \%$ compared to Shiwalik hills (36-49\%). The strong and sharp maxima at 10 $\mathrm{A}^{\circ}$ with its submultiple at 5 and $3.33 \mathrm{~A}^{\circ}$ in potassium as well as magnesium saturated clays which remained unaffected on glycolation (Mg clay) and heating upto $550 \square$ (K clay) confirmed its presence. The strong and sharp XRD peaks indicate that illite standard was highly crystalline. The $10^{\circ} \mathrm{A}$ reflections were slightly asymmetrical towards low $2 \theta$ angles particularly in clays of Ghaggar flood plain soils. This might be due to the replacement of interlayer potassium by hydrated cations leading to transformation into smectite and vermiculite group of minerals (Shanwal and Ghosh, 1987; Dutta, 2000).

Next to illite, a high amount of smectite (14-20\%) and vermiculite $(11-17 \%)$ were observed in clays of Ghaggar flood plain. However, these minerals were also detected in Shiwalik hills but in small amount (6$17 \%$ ). Shifting of $14^{\circ}$ A peaks to $\approx 18 \mathrm{~A}^{\circ}$ on glycolation of Mg-clay and reduction of $14^{\circ} \mathrm{A}$ peak in $\mathrm{K}$ clay on heating confirmed the presence of smectite and vermiculite, respectively. The presence of smectite in the soil could be attributed to alkaline soil $\mathrm{pH}$ condition and high exchangeable $\mathrm{Ca}$ and $\mathrm{Mg}$ that allows the neoformation of smectite in the soil (Duchaufour, 1998; Navarrete et al., 2011). Fairly good amount of kaolinite (10-17\%) and small amount (4-11\%) chlorite were uniformly distributed in soil clays irrespective of geomorphic units showing their detrital origin (Shanwal and Ghosh, 1987). Their presence was confirmed by disappearance of $7.2^{\circ} \mathrm{A}$ and persistence of $14^{\circ} \mathrm{A}$ peaks in K-clays on heating upto $550 \square$. Since the soils are relatively young, kaolinite seems of pedogenic origin rather than inherited from parent materials. The possible sources of pedogenic kaolinite are the weathering of vermiculite, chlorite and smectite (Navarrete et al., 2011).
Medium intensity broad peaks in higher range of diffractograms $\left(14-24^{\circ} \mathrm{A}\right)$ indicated the presence of regular and irregular interstratified minerals. The fairly good amount of interstratified minerals (9-15\%) in old alluvial plain (Ghaggar) supported the above mentioned hypothesis of potassium removal and illite weathering. A small amount of quartz was also observed in all the clay samples. However, feldspar was almost absent except negligible amount $(<5 \%)$ in one sample of Shiwalik valley clays. Therefore, mineralogical composition of clay is a function of weathering reaction during the process of soil development controlled by pedogenic features. By and large, the distribution of clay minerals is expected to bear close relation with climate and parent material. The diffractograms of clay fraction of pedons $2,5,8,15$ and 18 are presented in figures 5,$6 ; 7,8 ; 9,10 ; 11,12$ and 13 and 14 , respectively.

\section{Conclusion}

The soils have mixed mineralogy showing presence of quartz, mica and feldspars in sand and silt fractions and illite, smectite, vermiculite, kaolinite, chlorite and interstratified minerals in clay fraction. A fairly good amount of interstratified minerals in old alluvial plain supported the hypothesis of potassium removal and illite weathering. Study of mineralogy of such important soils helped us in understanding the potential nutrient reserves in the soil, degree of weathering and knowledge about soil development. The distribution of clay minerals in soils is expected to bear a close relationship with climate and zonal distribution. Since soil minerals primarily control the physical and chemical properties of soils particularly those minerals present in clay fraction, therefore, the study of mineralogy is imperative for understanding the nature of soils. The characteristics of the soils showed the considerable heterogeneity in profile, $\mathrm{pH}$, electrical conductivity and soil mineralogy irrespective of geomorphic units.

\section{REFERENCES}

Abbaslou, H., Abtahi, A., Peinado, F. J. M., Owliaie, H. and Khormali, F. (2013). Mineralogy and characteristics of soils developed on Persian Gulf and Oman sea basin, Southern Iran: Implications for soil evolution in relation to sedimentary parent material. Soil Sci., 178: 568-584

Ahuja, R. L. (1981). Pedogenic characterization of a part of Ghaggar river basin of Haryana. Ph.D thesis, HAU, Hisar.

Ahuja, R. L., Garalapuri, V. N. and Khanna, S. S., (1984). Fine sand mineralogy in relation to landforms of Ghaggar river basin in Haryana and Punjab. J. Indian Soc. Soil. Sci., 32(2): 707-715

Brady, N. C. and Weil, R. R., (2007). The Nature and Properties of Soils, 13th ed. Prentice Hall, Pearson Education, Inc.

Brindley, G. W and Brown, G. (1980). Crystal structures of clay minerals and their X-ray identification. London: 
Mineralogical Society, $495 \mathrm{Pp}$.

Buol, S. W., Southard, R. J., Graham, R.C. and McDaniel, P. A. (2011). Soil Genesis and Classification. Sixth Edition, John Wiley \& Sons Ltd, West Sussex, UK.

Chopra, S. (1990). A Geological cum Geomorphological Framework of Haryana and Adjoining Areas for Land use Appraisal Using Landsat Imagery. J. Indian Soc. Remote, 18(1):15-22

Churchman, G. J. (2010a). Is the geological concept of clay minerals appropriate for soil science? A literature-based and philosophical analysis. Phys. Chem. Earth, 35, 927940

Churchman, G. J. (2010b). The philosophical status of soil science. Geoderma, 157:214-221

Daniels, R.B., Gamble, E.E. and Cady, J.G. (1970). Some relations among coastal plains soils and geomorphic surfaces in North Carolina. Soil Sci. Soc. Am. Proc., 34:648-653

Duchaufour, P. (1998). Handbook of Pedology. A. A. Balkema, Rotterdam.

Dutta, S. (2000). Mineralogy and dynamics of potassium in some alluvial soils of semi-arid and humid regions of India. PhD Thesis, CCS HAU, Hisar.

Ghosh, S. K. and Duta, N. P. (1974). X-ray investigation of clay minerals in the soils of West Bengal. Proceedings of Indian National Science Academy, 40B:138

Gjems, O. (1967). Studies on clay minerals and clay mineral formation in soils profiles in Scandinavian Meddelser from Det Norske Skogforsak, Svesen, No. 81, Blind21, Volbeek, Norway.

Gupta, R. D., Bhan, D. and Kher, D. (2009). Mineralogy of sand and clay fractions from acidic soils of Jammu region. J. Indian Soc. Soil. Sci., 57(1): 39-44

Jassal, H. S., Sidhu, P. S., Sharma, B. D. and Mukhopadhyay, S. S. (2000). Mineralogy and geochemistry of some soils of Siwalik hills. J. Indian Soc. Soil. Sci., 48 (1): $163-172$

Kaistha, B. P. and Gupta, R. D. (1993). Morphology, mineralogy, genesis and classification of soils of the subhumid temperate high land of the central Himalayas. $J$. Indian Soc. Soil. Sci., 41(1):120-124

Karanthansis, A. D. and Hajek, B. F. (1982). Revised methods for quantitative determination of minerals in soil clays. Soil Sci. Soc. Am. J., 46: 419-425

Khan, Z. H., Mazumder, A. R., Hussain, M. S. and Saheed, S. M. (1997). Chemical and mineralogical properties of some benchmark soils of the floodplains of Bangladesh. J. Indian Soc. Soil. Sci., 45(2): 362-369

McBride, M. B. (1994). Environmental Chemistry of Soils. Published by Oxford University Press, Inc. 198 Madison Avenue, New York.

Moore, D. M., Reynold, R. C. (1989). X - Ray Diffraction and the Identification and Analysis of Clay Minerals. Oxford University Press, Inc. Oxford, New York. 332 p.

Navarrete, I. A., Tsutsuki, K., Asio, V. B., Tani, M. and
Sueta, J. (2011). Chemical, mineralogical and morphological characteristics of a late quaternary sedimentary rock-derived soils in Leyte, Phillipines. Soil Sci., 176 (12): 699-708

Raina, A. K., Sharma, S. D. and Jha, M. N. (2006). Sand and clay mineralogy of salt-affected soils of Uttar Pradesh. J. Indian Soc. Soil. Sci., 54:65-74

Sawhney, J. S., Deka, B., Sharma, B. D. and Sidhu, P. S. (1996). Magnitude of soil variability in morphological and other properties across different landscape in the Shiwalik hills of Punjab. J. Indian Soc. Soil. Sci., 44(3): 465-469

Shanwal, A. V and Ghosh, S. K. (1987). Soil on surfaces differing in age, Yamuna alluvial plains, India. Pedologie, XXXVII: 169-1186

Sharma, B. D., Mukhopadhyay, S. S. and Jassal, H. S. (2011). Morphological, chemical and mineralogical characterization of developing soils and their management in the western Siwalik Himalayas. Arch. Agron. Soil Sci., 57(96): 609-630

Sharma, B. D., Sidhu, P. S., Raj Kumar and Sawhney, J. S. (1997). Characterization, classification and landscape relationships of Inceptisols in north-west India. J. Indian Soc. Soil. Sci., 45(1): 167-174

Sidhu, P. S. (1982). Mineralogy of potassium in soils of Punjab, Haryana, Himachal Pradesh and Jammu and Kashmir. In: Sekhon GS, editor. Mineralogy of soil potassium. Gurgaon: Potash Research Institute of India. Pp. 6-14.

Sidhu, P. S. and Gilkes, R. J. (1977). Mineralogy of soils developed on alluvium in the Indo-Gangetic plains (India). Soil Sci. Soc. Am. J., 41:1194-1201

Sireesha, P. V. and Naidu, M. V. S. (2015). Clay Mineralogy of soils developed from granite-gneiss of Kurnool District in Andhra Pradesh. J. Indian Soc. Soil. Sci., 63(1): 16-23

Soil Conservation Service. (1972). Soil survey laboratory methods and procedures for collecting and analysing soil samples. Soil Survey Investigation Report 1. Washington (DC): United States Department of Agriculture.

Soil Survey Staff, (2006). Soil Taxonomy: A Basic system of Soil Classification for Making and Interpreting Soil Surveys, Second Edition. United States Department of Agriculture- National Resources Conservation Service, Agriculture Handbook, 436, US Government Printing Office, Washington, DC, USA.

Walia, C. S. and Rao, Y. S. (1997). Characteristics and classification of some soils of Trans-Yamuna plain. $J$. Indian. Soc. Soil. Sci., 45(1): 156-162

Wongpokhom, N., Kheoruenmne, I., Suddhiprakarn, A. and Gilkes, R. J. (2008). Micromorphological properties of salt affected soils in Northeast Thailand. Geoderma, 144(1-2): 158-170

Yadav, P. S. (1999). Pedogenic characterization of major landforms of Haryana. PhD Thesis, CCS HAU, Hisar. 